\title{
Hymen care for unmarried Muslim females: role of the forensic consultant in gynaecology interventions
}

H.A. Abder-Rahman'

$$
\begin{aligned}
& \text { العناية بغشاء البكارة لدى المسلمات غير المتزوجات: دور استشاريي الطب الشرعي في التدخلات النسائية } \\
& \text { حسن عبد الرحن }
\end{aligned}
$$

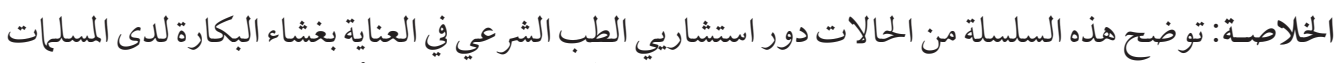

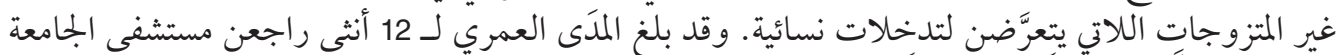

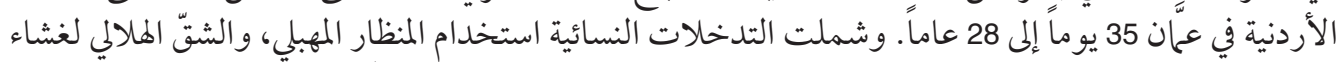

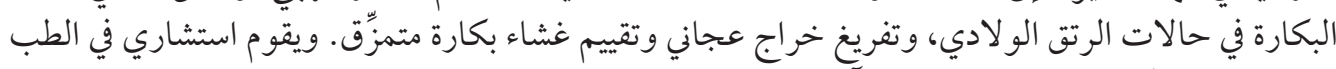

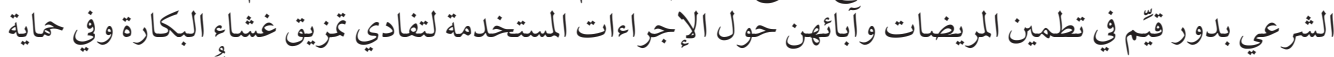

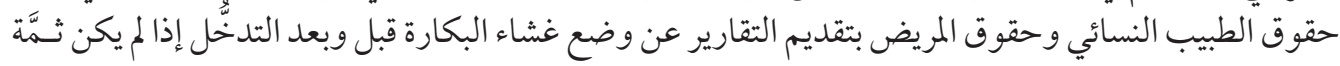

$$
\begin{aligned}
& \text { مفرّ من تعرضه للضرور. }
\end{aligned}
$$

ABSTRACT This case series illustrates the role of the forensic consultant in hymen care for unmarried Muslim females exposed to gynaecology interventions. The age range of the 12 females attending University of Jordan Hospital in Amman was 35 days to 28 years. Gynaecology interventions included the use of a vaginoscope, circular resection of the hymen in cases of congenital imperforate hymen, evacuation of perineal abscess and evaluation of a torn hymen. The forensic consultant provides a valuable role in reassuring patients and parents about procedures used to avoid rupturing the hymen, and in protecting the gynaecologist's and patients' rights by providing reports of the status of the hymen before and after intervention in cases where damage is unavoidable.

\begin{abstract}
Protection de l'hymen chez les femmes musulmanes non mariées : le rôle du conseiller en médecine légale lors d'interventions gynécologiques

RÉSUMÉ Cette série de cas illustre le rôle du conseiller en médecine légale du point de vue de la protection de l'hymen chez les musulmanes non mariées susceptibles de subir une intervention gynécologique. Les 12 patientes de l'hôpital universitaire de Jordanie à Amman étaient âgées de 35 jours à 28 ans. Les interventions gynécologiques comprenaient l'utilisation d'un vaginoscope, la résection circulaire de l'hymen en cas d'imperforation hyménéale congénitale, l'évacuation d'un abcès périnéal et l'évaluation d'un hymen rompu. Le conseiller en médecine légale joue un rôle précieux en rassurant les patientes et les parents à propos des procédures appliquées pour éviter la rupture de l'hymen, et en protégeant les droits des gynécologues et des patientes grâce à la communication d'informations sur l'état de l'hymen avant et après l'intervention, lorsque les dommages sont inévitables.
\end{abstract}

${ }^{1}$ Department of Forensic Medicine and Pathology, Faculty of Medicine, University of Jordan, Amman, Jordan (Correspondence to H.A.Abder-Rahman: toxico@ju.edu.jo).

Received: 18/10/06; accepted: 14/03/07

المجلة الصحية لشرق المتوسط، منظمة الصحة العالمية، المجلد الخامس عشر، العدد ع، 9 +. 


\section{Introduction}

Virginity, defined as an intact hymen, is considered a sign of sexual purity in Islamic societies and represents the honour of a woman and her family [1-4]. The loss of virginity before marriage is still a concern in many other cultures too, such as Chinese and Mediterranean societies [3]. In Jordan, as in many other Muslim countries, an intact hymen has such important social value that serious problems, crime or even blood feuds may arise if a newly married girl is found not to be a virgin $[1-3,5,6]$.

Most people believe incorrectly that fingers or other objects can never be inserted into the vagina for a fear of injuring the hymen [3]. Although in most cases the hymen will accommodate small intrusions without great difficulty, some gynaecologists and gynaecologic nurse practitioners are wary about examining unmarried women because of the fear of breaking the hymen, and often do pelvic examinations per rectum. Young females suffer a broad array of genital conditions which may need clinical evaluation and intervention: for example sexual abuse, gynaecological infections, trauma and more complex problems such as vaginal bleeding and benign and malignant conditions affecting the internal and external genitalia. Evaluation and treatment of such cases may need intervention via the hymen $[7,8]$.

Ethnic and crosscultural differences in women's attitudes in reproductive health care have not been adequately reported $[9,10]$. An electronic database search of the research literature published between 1965 and 2006 showed little attention to religious and cultural beliefs or values such as premarital virginity in the Muslim community in gynaecological health care [11]. In fact there was no published work discussing the proper way of dealing with gynaecological intervention in virgins.
This case series documents 12 cases to illustrate the important role of the forensic physician in cases of gynaecological intervention in unmarried Muslim females: first, the assurance to the patient and her parents that good medical practice respects cultural attitudes towards the hymen and endeavours to safeguard the intact hymen; and, second, the protection of the gynaecologist's and the patient's rights in case the intervention necessitates damaging the hymen. It is hoped that this approach will be considered seriously by medical associations and agencies throughout the world in their guidelines for providing intimate examinations for Muslim and other communities.

\section{Methods}

In 2005, while working in the Department of Forensic Medicine, University of Jordan Hospital, the author was consulted to witness and to evaluate 20 preadolescent girls and single women who needed gynaecological intervention. The interventions were carried out around or through the hymen area under general anaesthesia by gynaecologists at the Department of Gynaecology and Obstetrics. The forensic role was mainly concerned with formal documentation of the pre- and postintervention state of the hymen. Parents of minors, or the patient herself if over 18 years, signed consent forms in compliance with the hospital standards.

The Department of Forensic Medicine, a university-affiliated department, evaluates female patients and children each year for possible abuse, sexual offences and anogenital trauma. The department is available for cases referred by law enforcement agencies and emergency departments and clinics throughout the University of Jordan Hospital, as well as self-referrals. The Department of Forensic Medicine policy/ 
protocols dictate that any case with hymenal trauma and or any medicolegal case will be followed up in the forensic clinic and a formal medicolegal report will be issued.

\section{Results}

The mean age of the 20 females was 16.4 years (range: 35 days to 28 years). Due to the similarity in the clinical presentation between some cases, only 12 cases were chosen to represent the different aspects of hymen care (Table 1).

The first 2 cases were girls with vaginal foreign bodies. Case 1 was an 8-year-old girl who had rolled-up pieces of toilet tissue in the vagina, while case 2 was a 6 -year-old girl who had a metallic hairpin inserted.
Both children were complaining of bloody vaginal discharge. Removal of the toilet tissue needed 2 rounds of operations under general anaesthesia, and forensic consultation took place during the second operation. The hymen of the first child was found to be intact while that of the second one showed an old tear at 8 o'clock.

The next 2 cases were trauma cases. Case 3 was a 4-year-old girl who sustained a direct genital trauma while playing. She had a straddle injury to the genitalia. Local examination revealed contusion of the labia majora and minora together with a recent hymenal tear at 6 o'clock. Plastic surgical repair was carried out 1 month later but without success and the hymen remained torn. Case 4 was an 8-year-old girl who

Table 1 Gynaecological interventions in girls and young unmarried women involving forensic consultation: summary of 12 cases

\begin{tabular}{|c|c|c|c|c|c|}
\hline $\begin{array}{l}\text { Case } \\
\text { no. }\end{array}$ & $\begin{array}{c}\text { Age } \\
\text { (years) }\end{array}$ & Diagnosis & Procedure $^{a}$ & Hymen status & $\begin{array}{c}\text { Forensic } \\
\text { documentation }\end{array}$ \\
\hline 1 & 8 & Vaginal foreign body & $\begin{array}{l}\text { Exploration and } \\
\text { removal }\end{array}$ & Intact & File notes \\
\hline 2 & 6 & Vaginal foreign body & Removal & Old tear & Report \\
\hline 3 & 4 & Fall with genital injury & Exploration and repair & Recent tear & Report \\
\hline $4^{b}$ & 8 & $\begin{array}{l}\text { Road accident with pelvic } \\
\text { injury and fractures }\end{array}$ & Exploration and repair & Recent tear & Report \\
\hline 5 & 22 & $\begin{array}{l}\text { Suspected vesicovaginal } \\
\text { fistula }\end{array}$ & Exploration & $\begin{array}{c}\text { Absent, with } \\
\text { small remnant of } \\
\text { hymen }\end{array}$ & Report \\
\hline 6 & 27 & $\begin{array}{l}\text { Suspected recto-vaginal } \\
\text { fistula }\end{array}$ & Exploration & Intact & File notes \\
\hline 7 & 20 & $\begin{array}{l}\text { Large cervical polyp } \\
\text { protruding through hymen }\end{array}$ & $\begin{array}{l}\text { Exploration and } \\
\text { excision }\end{array}$ & Intact & File notes \\
\hline 8 & 28 & Cervical polyp & $\begin{array}{l}\text { Exploration and } \\
\text { excision }\end{array}$ & Intact & File notes \\
\hline 9 & 21 & Imperforate hymen & Partial excision & Annular & Report \\
\hline $10^{\mathrm{b}}$ & 35 days & Imperforate hymen & Partial excision & Annular & $\begin{array}{c}\text { File notes, report } \\
\text { postponed }\end{array}$ \\
\hline 11 & 19 & Abscess in labia minora & Evacuation & Unexamined & File notes \\
\hline 12 & 19 & Perineal abscess & Evacuation & Unexamined & File notes \\
\hline
\end{tabular}

${ }^{a}$ Procedures were carried out under general anaesthesia.

${ }^{b}$ Consultation of these cases for the gynaecologist and the forensic physician was carried out by a paediatric surgeon.

المجلة الصحية لشرق المتوسط، منظمة الصحة العالمية، المجلد الخامس عشر، العدد ع، 9 ب. 
was involved in a road traffic accident. She had severe pelvic injury and fractures. The hymen was found to be torn at 7 o'clock. Examination of the case after 6 months revealed the same appearance of the hymen.

Case 5 had been involved in a road traffic accident when she was 8 years old. She suffered from severe pelvic trauma with fractures and severe lacerations. She developed recurrent vaginal discharge and burning micturition. After 14 years, exploration of this case to rule out the possibility of vesicovaginal fistula revealed that the hymen was completely absent with just a small remnant of hymenal tissue in place.

Cases 6, 7 and 8 illustrate the use of the vaginoscope introduced through the hymenal orifice to the vagina. Case 6 had had a previous surgical operation in the anus. Exploration of the vagina was done to exclude the possibility of rectovaginal fistula. Case 7 had a large cervical polyp protruding through the hymenal orifice. Resection of the polyp was done. Case 8 had resection of a polyp followed by dilatation of the cervix by Hegar's dilators to explore the uterus for the presence of uterine polyps. After the end of the operation, in both cases the hymen remained intact.

Cases 9 and 10 were had congenital imperforate hymen which required circular resection of the hymen. Case 9 had no menstruation, so laparatomy and vaginal exploration was needed to rule out the possibility of vaginal and cervical atresia. Vaginal adhesion was found when Hegar's dilators were used. Case 10 presented with a pelvi-abdominal mass. Exploration showed that the mass was an enlarged uterus. The hymen was examined and found to be imperforate. Due to the fear of reclosure of the hymen or the need for further gynaecological intervention, a repeat follow-up for case 10 was decided. In both cases, the remaining part of the hymen was annular.
In cases 11 and 12, evacuation of an abscess in the labia minora and in the perineal region took place. No effort was made to examine the hymen, as it was not involved in the investigation.

Forensic notes were written on the patient's file for all cases. They included detailed consent, history, clinical diagnosis, medical manipulation and the pre- and postoperative condition of the hymen. Forensic re-examination of cases 2, 3, 4, 5 and 9 was done and formal medicolegal reports were issued. Issuing a report for case 10 was postponed until cure was complete. Evaluation of cases 1, 2 and 3 showed no evidence of sexual abuse.

\section{Discussion}

In cases where gynaecological intervention is indicated in single girls around and/ or through the hymen, the patient and or her parents usually express deep concern about the integrity of the hymen. Moreover, the gynaecologists are afraid of future allegations. In Jordan, the role of the forensic physician is starting to be appreciated in cases of gynaecological intervention in unmarried females. The above-mentioned cases were used to set an example of cases where a forensic doctor was consulted by the gynaecologists.

The age of the studied cases ranged from 35 days to 28 years. Thus they fall into very different groups with different gynaecological needs. In all cases there was extreme concern about the integrity of the hymen.

Gynaecological surgical interventions were indicated in case of acute genital trauma (cases 3 and 4), imperforate hymen (cases 9 and 10), foreign bodies in the vagina (cases 1 and 2), polyps or tumours (cases 7 and 8), genital abscesses (cases 11 and 12) and for diagnostic purposes (cases 5 and 6 ). 
Bleeding from the vulva or vagina in young girls should be promptly evaluated because it causes both the child and her parents considerable concern. This was evident in case 3 and 4 with a tear to the hymen and in cases 1 and 2 with vaginal foreign bodies. Surgical and diagnostic procedures may also cause genital bleeding. The witness of a forensic doctor is important, as the source of bleeding should be promptly evaluated. The patient or her parents probably cannot pinpoint the source of the bleeding and may mistakenly believe it is from the hymen, as seen in case 11 with labial abscess.

For many women in our society, loss of virginity virtually ends any possibility of marriage. Any physical rupture of the hymen, regardless of whether it is unconnected to sexual activity, is considered evidence of lost virginity [3]. In case 3 , where the hymen was found to be torn, the family was worried when forensic examination revealed a nonhealed injury. They requested plastic surgery repair of the hymen, which was unsuccessful on 2 attempts. Although the girl is a still young, her parents were very concerned about her future marriage prospects. In case 5 , the girl and her parents were extremely shocked when informed about the hymen. Although they knew that their daughter had suffered a severe trauma in the past, they did not know that the hymen was damaged. Their focus of concern then moved from the medical problem to the hymen. The hymen issue is so crucial that in some cases, as in case 7 , a young woman may contemplate suicide rather than being injured during gynaecological intervention.

There are limited published cases on the healing of hymenal tears. The hymen usually has a better chance of healing in cases of partial tear than complete ones. Full transection of the hymen cannot heal without surgical repair. Even then, only a small percentage of fully transected hymens can be successfully repaired [12]. This was evident in case 3 where surgical repairs were tried and in the follow-up of case 4 without surgical repair.

Although it is acceptable in some societies for a single girl to do surgical widening of the hymen, especially in cases of microperforate and septate types, to be able to get a tampon into her vagina, it is completely prohibited in other societies due to the fear of loss of virginity. Moreover, in cases of imperforate hymen, as in cases 9 and 10, it is recommended to open the hymenal membrane using a circular incision following the lines of the normal annular hymenal configuration.

Although the majority of the patients examined were Muslims, case 8 was a Christian woman. This illustrates the cultural importance of the hymen issue. Although in many societies young women today do not give any thought to the status of their hymen, the focus on female virginity is not exclusive to Jordan. In societies as diverse as other Muslim countries, Asia, South America, and even Europe and North America, female virginity is emphasized as an important social norm that operates as a means of controlling women's behaviour [3].

In Jordan, forensic physicians are considered to be the most qualified doctors for dealing with virginity examinations, while in other countries the examination is still also carried out by gynaecologists and even by general practitioners [13]. The attendance at and follow-up of the gynaecology procedures by forensic physicians can assure both the gynaecologist and the patient and her family of the soundness of the procedures.

An advantage of the forensic physician is to encourage the gynaecologist to do everything possible to protect the hymen. For example, when the doctor's attention is focused on performing procedures such

المجلة الصحية لشرق المتوسط، منظمة الصحة العالمية، المجلد الخامس عشر، العدد ع، 9 +. 
as colposcopy or hysteroscopy, the forensic physician can watch the status of the hymen. The gynaecologist can then feel more secure in carrying out the appropriate vaginal intervention, as seen in cases 1,9 and 10. This is also explained by forensic consultations in cases of gynaecological intervention outside the region of the hymen, as noted in case of labial abscess (case 11) and perineal abscess (case 12). Although these last 2 cases did not need any object to be passed through the hymen into the vagina, their inclusion aims to highlight the extent of worry experienced by parents when medical interventions approach the anogenital area.

The presence of a forensic physician also protects doctors against false allegations of malpractice during an intimate examination. Gynaecologists are generally wary of examining single women for fear of future allegations, especially in cases of repeated gynaecological intervention, as shown in cases 1 and 9 , or when there is a tear in the hymen, as seen in cases 2, 3 and 5. In addition, the forensic physician has to rule out the possibility of sexual molestation, as in case 3 with a hymen tear and in cases 1 and 2 with vaginal foreign bodies.

The patient and/or her family feel more comfortable and less anxious when there is a forensic consultant involved. In many instances, parents believe that issuing a formal forensic report protects their daughter's reputation by providing tangible "proof" that the girl or woman remains a virgin despite gynaecological intervention through the hymen (cases $1,6,7,8$ ) or by establishing with medical evidence that the girl or woman's hymen was ruptured in an accident and not as a result of extramarital sexual activity (cases 2, 3, 4, 5). On the other hand, the patient and her family can also be assured that every effort will be taken not to break the hymen (cases $1,6,7,8$ ) or even not to touch it at all (case 11, 12). Moreover, in case of imperforate hymen, surgical incision will be done in a way to keep the hymen annular and intact (cases 9, 10).

\section{Recommendations}

Although implementation is far from universal in clinical practice, the care of unmarried females can be improved if their gynaecological health is addressed with the cooperation of a forensic physician.

- The first step in forensic documentation is to take a complete history. Then the gynaecologist discusses the case with the girl and/or her family, with the help of the forensic doctor, in order to explain the gynaecological procedures and the expected effect on the hymen, if any. The doctor must make sure that both the patient and the legal guardian are capable of understanding the nature and possible dangers of the operation. The possibility of hymenal tear and injuries during surgical intervention must be made clear.

- Contrary to the consent for other medical procedures which is usually taken from the patient herself or in case of minors from her parents, written consent from parents is obligatory for all gynaecology interventions involving minors and even adult single women.

- When talking with the patient and her parents, in case of simple intervention and in procedures that will not affect the hymen, it is important to carefully explain that the girl's hymen will not be altered in any way by the examination, because many parents do not fully understand the anatomy of the vagina and hymen. They mistakenly believe that anything which enters the vagina will automatically tear the hymen. Basic 
diagrams of the anatomy may be helpful in discussions.

- The forensic doctor should witness the gynaecology procedure from its start to its end and write a detailed description of the pelvic examination, the diagnostic tools used or the surgical procedures done and the effect if any on the hymen. $\mathrm{He} / \mathrm{she}$ should issue a report in cases of hymenal tear.

- Finally, it is important that, whenever possible during interventions, every ef- fort should be made to keep the hymen intact. The extreme concern and pressure upon medical practitioners and women in Islamic cultures to preserve the integrity of the hymen may be difficult for those from other cultures to comprehend. In spite of that, the role for forensic medicine proposed in this paper is an example of how physicians throughout the world can improve their gynaecological health care to unmarried Muslim women by taking care of the hymen.

\section{References}

1. Rashid SF, Michaud S. Female adolescents and their sexuality: notions of honour, shame, purity and pollution during the floods. Disasters, 2000, 24(1):54-70.

2. Kandela P. Egypt's trade in hymen repair. Lancet, 1996, 347:1615.

3. Shalhoub-Kevorkian NR. Imposition of virginity testing: a life-saver or a license to kill? Social science and medicine, 2005, 60:1187-96.

4. Frank MW et al. Virginity examinations in Turkey: role of forensic physicians in controlling female sexuality. Journal of the American Medical Association, 1999, 282:485-90.

5. Shalhoub-Kevorkian N. Femicide and the Palestinian criminal justice system: seeds of change in the context of state building? Law and society review, 2003, 36(3):577-605.

6. Elnekave E, Gross R. The healthcare experiences of Arab Israeli women in a reformed healthcare system. Health policy, 2004, 69(1):101-16.

7. Gidwani GP. Approach to evaluation of the premenarchal child with a gynecologic problem. Clinical obstetrics and gynecology, 1987, 30:643-52.
8. Blake J. Gynaecologic examination of the teenager and young child. Obstetrics and gynecology clinics of North America, 1992, 19:27-38.

9. Ekeroma A, Harillal M. Women's choice in the gender and ethnicity of her obstetrician and gynaecologist. Australian and New Zealand journal of obstetrics and gynaecology, 2003, 43:345-9.

10. Uskul AK, Ahmad F. Physician-patient interaction: a gynecology clinic in Turkey. Social science and medicine, 2003, 57:205-15.

11. Matin M, Le Baron S. Attitudes toward cervical cancer screening among Muslim women: a pilot study. Women and health, 2004, 39(3):63-77.

12. Heppenstall-Heger A et al. Healing patterns in anogenital injuries: a longitudinal study of injuries associated with sexual abuse, accidental injuries, or genital surgery in the preadolescent child. Pediatrics, 2003, 112(4):829-37.

13. Alkan N et al. Gynecological examinations for social and legal reasons in Turkey: hospital data. Croatian medical journal 2002, 43(3):338-41. 